\title{
An Overview of Historical Channel Adjustment and Selected Hydraulic Values in the Lower Sabine and Lower Brazos River Basins, Texas and Louisiana
}

The Sabine and Brazos are alluvial rivers; alluvial rivers are dynamic systems that adjust their geometry in response to changes in streamflow (discharge) and sediment load. In fluvial geomorphology, the term "channel adjustment" refers to river channel changes in three geometric dimensions: (1) channel slope (profile); (2) the outline or shape, such as meandering or braided, projected on a horizontal plane (planform); and (3) cross-sectional form (shape). The primary objective of the study was to investigate how the channel morphology of these rivers has changed in response to reservoirs and other anthropogenic disturbances that have altered streamflow and sediment load. The results of this study are expected to aid ecological assessments in the lower Sabine River and lower Brazos River Basins for the Texas Instream Flow Program. Starting in the 1920s, several dams have been constructed on the Sabine and Brazos Rivers and their tributaries, and numerous bridges have been built and sometimes replaced multiple times, which have changed the natural flow regime and reduced or altered sediment loads downstream. Changes in channel geometry over time can reduce channel conveyance and thus streamflow, which can have adverse ecological effects. Channel attributes including cross-section form, channel slope, and planform change were evaluated to learn how each river's morphology changed over many years in response to natural and anthropogenic disturbances. Climate has large influence on the hydrologic regimes of the lower Sabine and lower Brazos River Basins. Equally important as climate in controlling the hydrologic regime of the two river systems are numerous reservoirs that regulate downstream flow releases. The hydrologic regimes of the two rivers and their tributaries reflect the combined influences of climate, flow regulation, and drainage area. Historical and contemporary cross-sectional channel geometries at 15 streamflow-gaging stations in the lower Sabine and lower Brazos River Basins were evaluated (fig. 1). An in-depth discussion of results from streamflow-gaging station 08028500 Sabine River near Bon Weir, Tex. (fig. 2), is featured here as an example of the analyses that were done at each station.

This study, done by the U.S. Geological Survey (USGS) in cooperation with the Texas Water Development Board, documents methods used to reconstruct historical channel geometry, establish trends in channel adjustment, and infer causes of that change. The primary sources of historical channel morphology information were USGS hard-copy discharge-measurement field notes. Additional analyses were done using computations of selected flow hydraulics, comparisons of historical and contemporary aerial photographs, comparisons of historical and

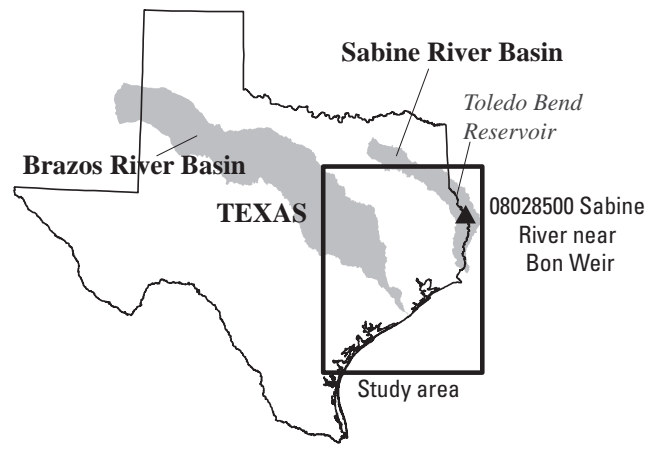

Figure 1. Location of study area where U.S. Geological Survey streamflow-gaging stations were examined for cross-sectional channel adjustment using historical field-measurement data, lower Sabine and lower Brazos River Basins, Texas and Louisiana.

contemporary ground photographs, evaluations of how frequently stage-discharge rating curves were updated, reviews of stage-discharge relations for field measurements, and considerations of bridge and reservoir construction activities. Advances in data collection over time, including aerial photographic surveys, satellite imagery, ground-elevation surveying improvements, and, most recently, Light Detection And Ranging (LiDAR) technology were used to augment information obtained from measurement field notes. Improvements in computational resources, notably the development of sophisticated geographic information system (GIS) technology, have also enabled relatively rapid quantitative assessments of channel adjustment through time. One of the basic requirements for assessing channel adjustment is establishing change or constancy in shape and bed elevation through time. To do so requires (1) elevation measurements of the channel bed and banks at a consistent location through time and (2) documentation of the reference elevation datum, whether geographic (North American Vertical Datum of 1929) or arbitrary (site specific). The USGS has operated thousands of streamflow-gaging stations in the United States since 1889, each with the specific purpose of quantifying the volume of flow in the river or stream through time, as well as other data-collection activities. Of these gaging stations, almost 15,000 have discharge-measurement field data for various periods of record, summarized in the USGS National Water Information System (NWIS). Dischargemeasurement field data include water-surface width in feet, flow depth in feet, and flow velocity in feet per second, which are used to compute discharge in cubic feet per second. 


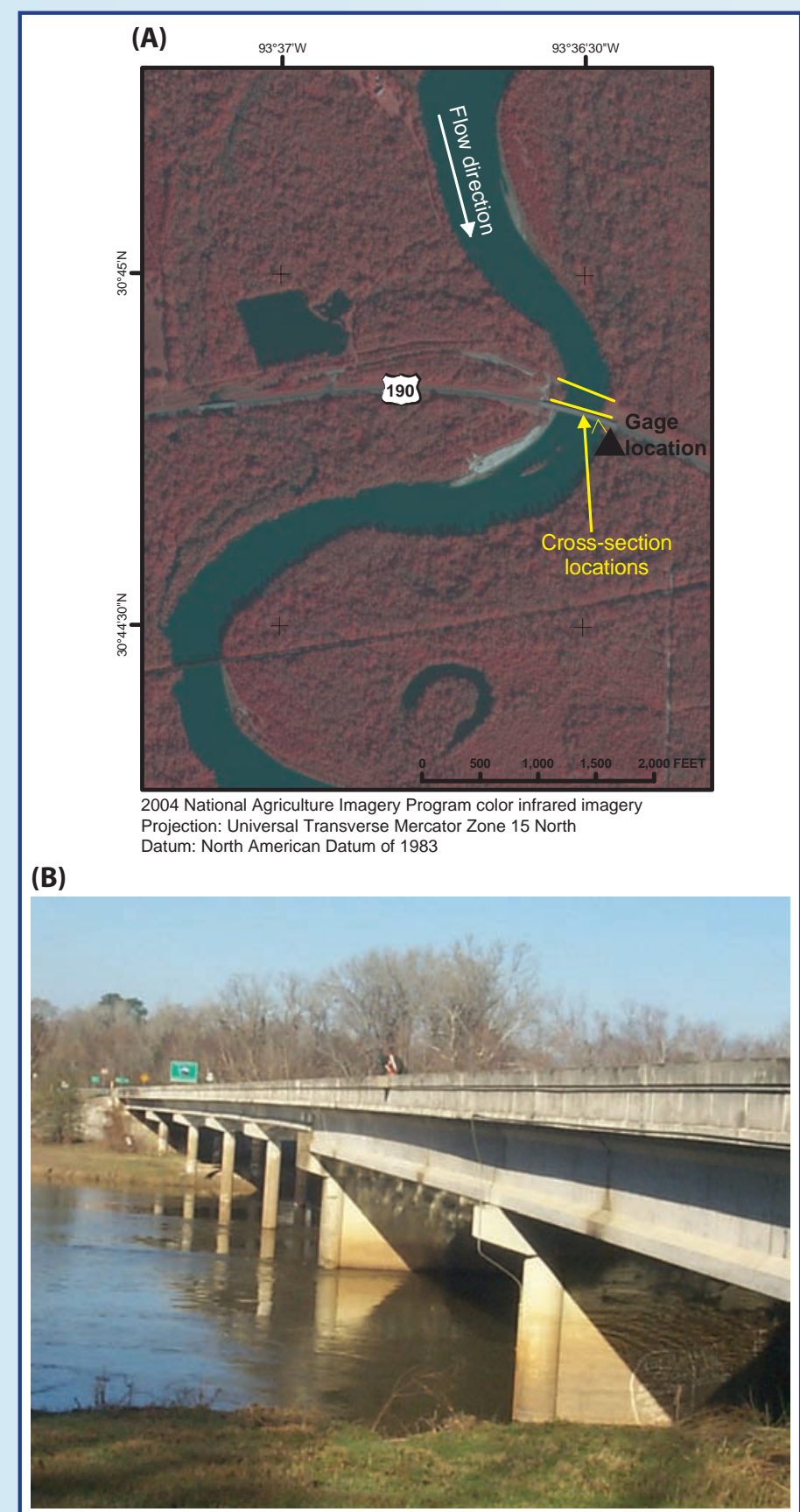

Figure 2. U.S. Geological Survey streamflow-gaging station 08028500 Sabine River near Bon Wier, Texas, (A) 2004 digital orthophoto quarter-quadrangle; and (B) photograph looking from left bank adjacent to U.S. Highway 190 bridge, May 30, 1999.

\section{Use of Historical Cross Sections from USGS Streamflow Measurement Data to Evaluate Channel Adjustments}

USGS hard-copy field-measurement notes provide the primary source of data for constructing historical channel cross sections in the lower Sabine and lower Brazos River Basins. For the streamflow-gaging stations investigated in this study, discharge measurement notes for approximately the last 30 years were available at the USGS Texas Water Science Center offices in Austin and Houston, and older records were obtained from the Federal Archives in Fort Worth. USGS hydrologic technicians record hydraulic properties including water-surface elevation and channel-geometry information (cross-section area, hydraulic radius, and water-surface width) when measuring discharge. Estimates of additional hydraulic properties including channel slope and Manning's $n$ roughness coefficient were derived by the authors. An approximate value of channel slope at each gaging station was determined by extracting upstream and downstream channel elevations from 10-meter digital elevation models (DEMs) using historical information obtained from streamflow measurements. Manning's $n$ roughness coefficients were computed using hydraulic radius and channel slope adjusted for each hydraulic computation to provide the closest match to the known streamflow.

\section{Alternative Techniques and Additional Sources of Data for Interpreting Channel Adjustment}

A variety of alternative techniques and other sources of data were used to aid interpretation of historical cross-sectional geometry and channel hydraulics through time. These include assessments of USGS stage-discharge rating curves, stagedischarge relations of field measurements, historical and contemporary aerial and ground photography, and bridge construction information for the streamflow-gaging stations investigated in this study. The contemporary aerial photography consisted of digital orthophoto quarter-quadrangles from 2004.

Stage-discharge rating curves are developed and updated over time for USGS streamflow-gaging stations. Cross-sectional geomorphic change can result in the need for a revision to a stage-discharge rating curve either because the capacity of a channel to convey streamflow is directly related to crosssectional area or because local bed scour or fill results in a different water-surface elevation for a given discharge. For example, progressive incision, or lowering, of a channel bed through time results in decreasing stage values for a given streamflow.

As part of maintaining a USGS streamflow-gaging station, field measurements of discharge are summarized using USGS Form 9-207, which includes the discharge, gage height, width, cross-sectional area, mean velocity, and other data for all measurements made at one station. For the gaging stations investigated in this study, relations of measured gage height to measured discharge were analyzed for all digitally available measurements for the period of record. Analyses of stagedischarge relations of field measurements were done to complement and reinforce interpretations of channel adjustment made from historical cross sections.

Some of the planform metrics associated with channel geometry that can be measured from aerial photography include meander wavelength, curvature, and channel width. The chronology of riparian landscape changes, including channel cutoffs and vegetation density, can also be inferred using aerial photographs. By comparing historical and more contemporary aerial photographs at a given site, time-averaged rates of various fluvial processes were inferred, including channel migration, bank erosion, point-bar accretion, and channel-bar development.

\section{Sabine River near Bon Weir, Texas}

The Sabine River near Bon Weir, Tex., streamflow-gaging station (08028500) is located at a bridge along U.S. Highway 


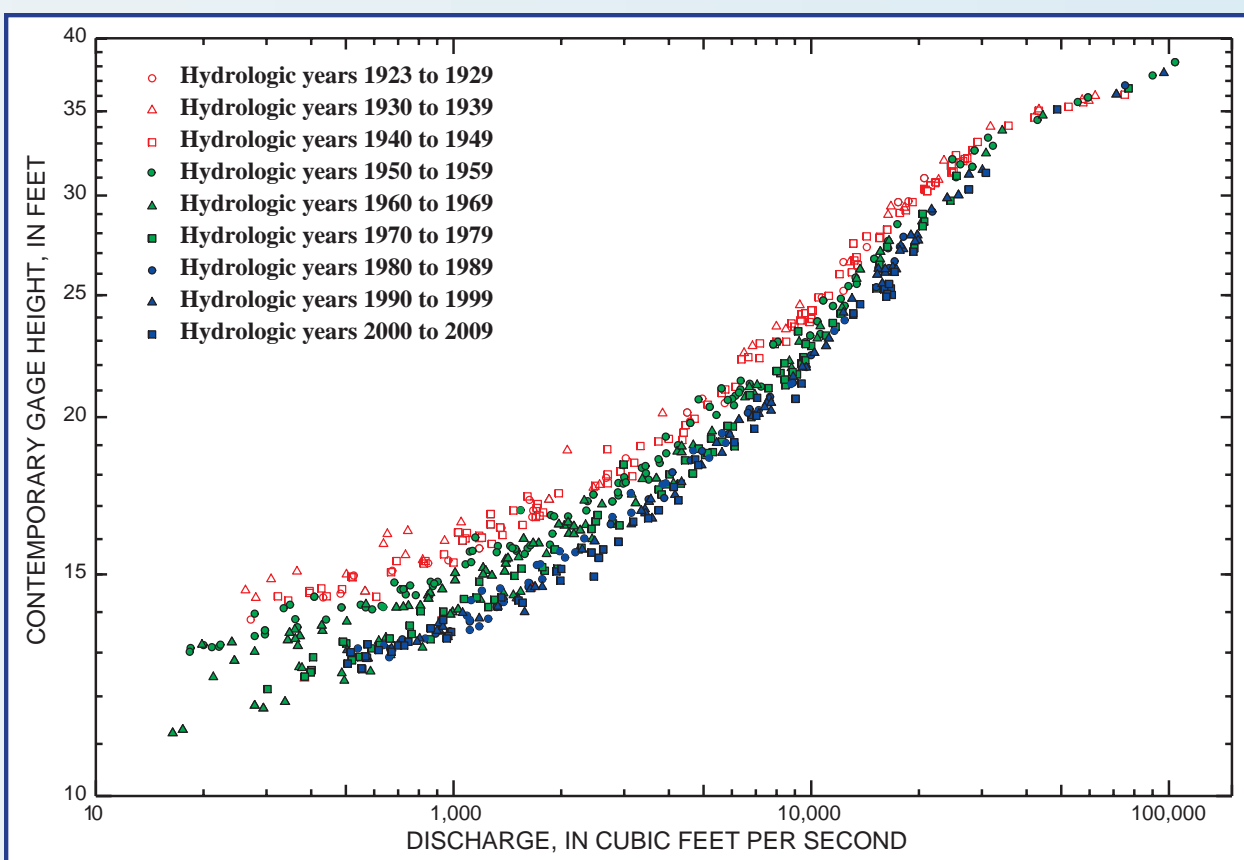

Figure 3. Stage-discharge relations of field measurements for U.S. Geological Survey streamflow-gaging station 08028500 Sabine River near Bon Wier, Texas, 1923-2009.
The measurement site is at a meander bend and the asymmetrical cross-sectional geometry shows the gradual right point bar descending to the thalweg near the left cutbank side of the channel (fig. 4). Between 1933 and 1940, an aggradational episode at the site filled the thalweg near the cutbank with nearly 13 feet of sediment and incised a new elevated thalweg across the point bar; and the channel cross section dramatically changed its geometry (fig. 4A, B). Between 1940 and 1980, the channel gradually reestablished asymmetry at the site with the thalweg on the left, or outside the meander bend. The elevation and uniform transverse slope of the early 1930s point-bar surface, however, was not fully restored by the late 1970s. A progressive pattern of channel incision is not detected, either in moderate-flow or high-flow cross sections. Cutbank migration is not detected for moderate flows (fig. 4A) but is detected for high 190 downstream from Toledo Bend Reservoir, and the sandbed river forms the boundary between Texas and Louisiana (figs. 1, 2). Streamflow measurements at the site began in October 1923 and continue to present (2009); 17 stage-discharge rating curves have been used for the period of record. Rating curves were most frequently updated between 1950 and 1953. Stage-discharge relations determined from field measurements for the period of record indicate progressive channel degradation since the 1930s (fig. 3). The bridge at this site was replaced in 1981, thus two sequences of historical cross sections are provided because: (1) the bridge and discharge-measurement site were relocated about 200 feet downstream; (2) USGS measurement cross-section distances were changed; and (3) construction activity might have altered channel geometry. flows between 1932 and 1966 (fig. 4B) and amounts to approximately 30 feet, or an average of 0.88 foot per year.

Since 1981, the cross-sectional geometry at the new bridge location is narrower and has a steeper right bank (fig. 4C, D) than the former bridge location. Since the mid-1980s, minor adjustment of the channel-bed elevation has occurred several times, which is common for sand-bed rivers. More distinctive, however, is the apparent migration of the channel thalweg to the right. Between 1984 and 2005, the thalweg has moved approximately 30 feet to the right, or an average of 1.43 feet per year, and the left channel bank has moved approximately 15 feet to the right, or an average of 0.71 foot per year. A number of large floods have occurred along the lower Sabine River during this time, including a peak of 98,200 cubic feet per second in July
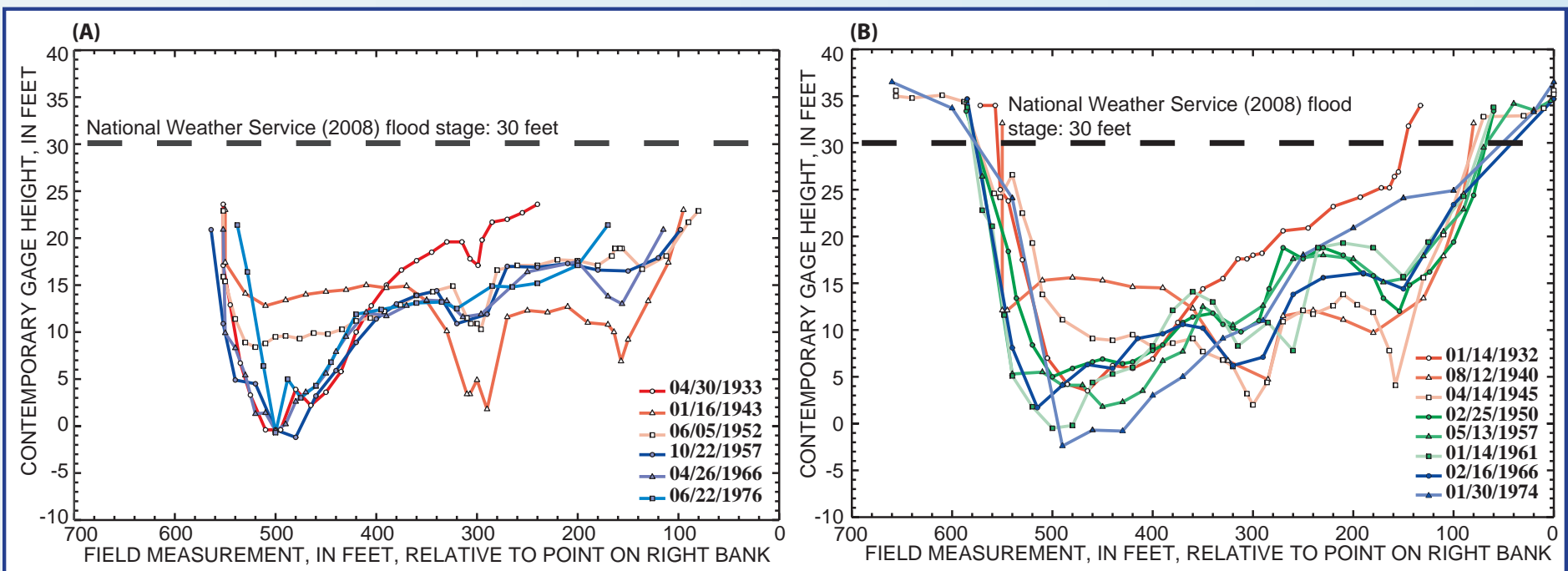

Figure 4. Historical cross-sectional channel geometry for U.S. Geological Survey streamflow-gaging station 08028500 Sabine River near Bon Wier, Texas, (A) at moderate-flow conditions (greater than 5,000 cubic feet per second and less than 10,000 cubic feet per second), 1933-76; (B) at high-flow conditions (greater than 10,000 cubic feet per second), 1932-74; (C) at moderate-flow conditions, 1986-2005; and (D) at high-flow conditions, 1984-2003. 


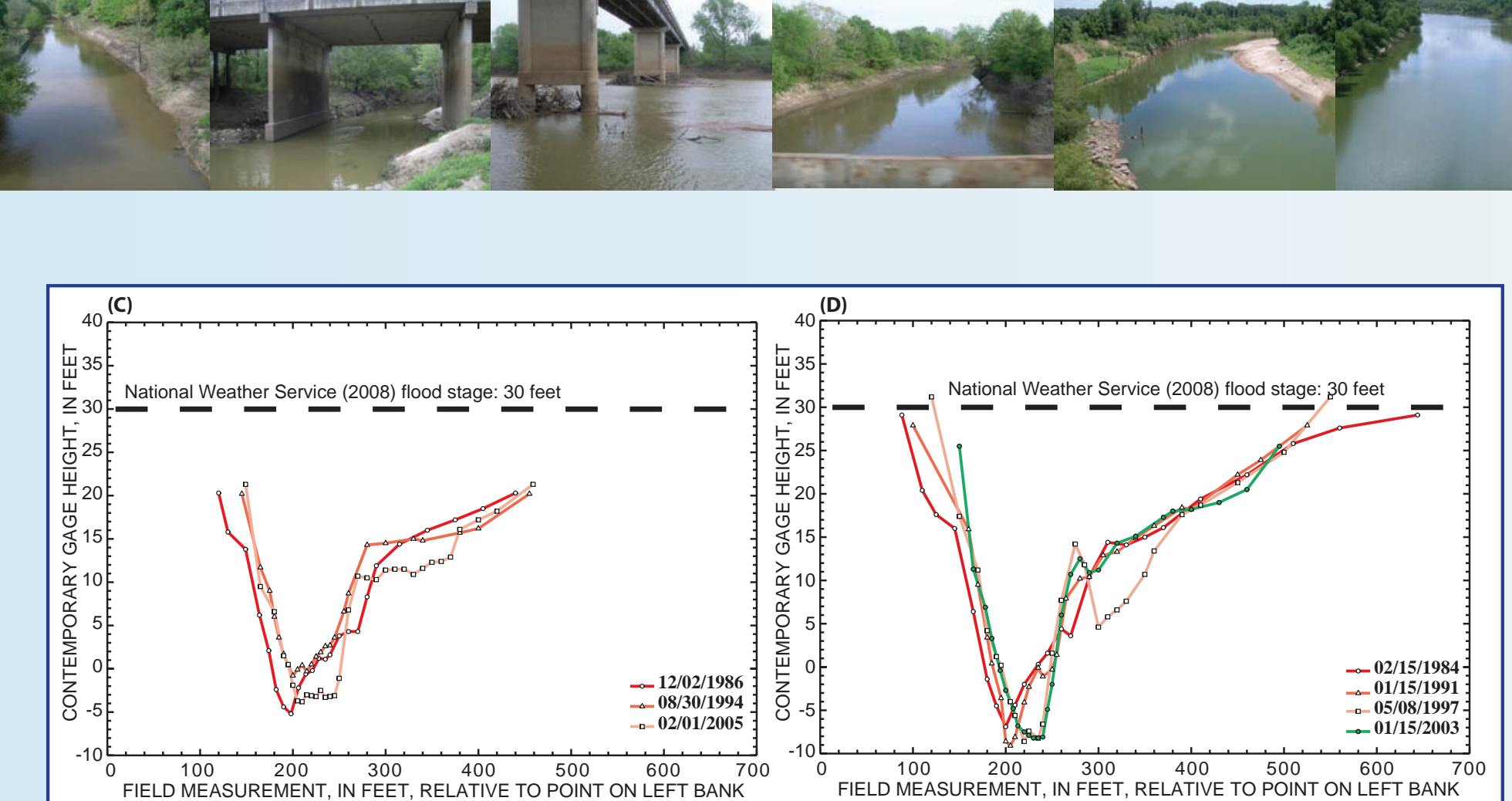

Figure 4.-Continued.

1989 and 92,600 cubic feet per second in February 1999. These high-magnitude floods, combined with hydraulic changes associated with bridge construction in 1981, might explain migration of the thalweg to the right. Further evidence of the thalweg migration is shown by the chute cutoff of the point bar immediately downstream from the bridge (fig. 2A), which stranded a small point-bar ridge as an island. The apparent contraction of the left channel bank probably is related to anthropogenic bankstabilization efforts to prevent erosion near the bridge structure and not because of natural deposition along the cutbank.

The morphological results generally support observations of channel shape and interpretations of adjustment at this site made by other investigators, including a steep left bank and a gradually sloping bar surface on the right side. Historical cross sections (fig. 4) confirm the steep left bank, but the gradually sloping bar is steeper on the right side of the channel at the USGS cross-section location. Further, the downstream migration of the right point-bar deposit between 1994 and 2000 is confirmed by historical cross sections, indicating that the bar fully migrated downstream between 1994 and 1997.

Considerable variability through time is evident for width, depth, area, and velocity of the Sabine River near Bon Wier, mostly because of the 1930s episode of aggradation followed by the recovery of the channel to an asymmetrical shape. During the last 20 years, or since the bridge and measurement sections were moved downstream, channel hydraulics were generally stable compared to the previous 50 years.

\section{Reference}

\section{This fact sheet is based on the following USGS report:}

Heitmuller, F.T., and Greene, L.E., 2009, Historical channel adjustment and estimates of selected hydraulic values in the lower Sabine River and lower Brazos River Basins, Texas and Louisiana: U.S. Geological Survey Scientific Investigations Report 2009-5174, 143 p.

\section{By Franklin T. Heitmuller, Lauren E. Greene, and John D. Gordon}

\section{For additional information contact:}

Director, Texas Water Science Center

U.S. Geological Survey

1505 Ferguson Lane

Austin, Texas 78754-4501

World Wide Web: http://tx.usgs.gov/

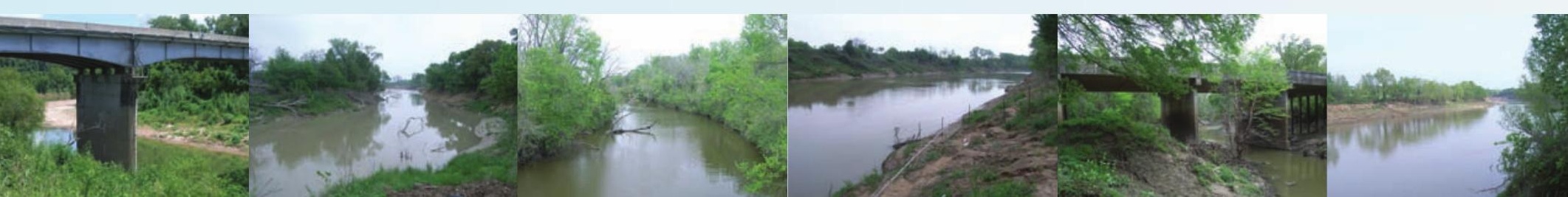

